\title{
Application of DNA Fingerprinting to Investigation of Genetic Relationships between Laboratory Rabbit Strains
}

\author{
Toshiki SUDO***, Soichi TSUJI, Hideyuki MANNEN, Nobuo GOTO, Hidehiko \\ UMEZAWA*, Makoto MIZUTANI*, Hajime YAZAWA*, \\ and Masashi SHIOMI** \\ Laboratory of Animal Breeding, Faculty of Agriculture, Kobe University, 1 Rokkodai, Kobe-shi, \\ Hyogo 657, *Nippon Institute for Biological Science, Laboratory Animal Research Station, \\ Kobuchizawa, Yamanashi 409-16, and ${ }^{* *}$ Institute for Experimental Animals, \\ Kobe University School of Medicine, 7 Kusunoki-cho, \\ Chuo-ku, Kobe-Shi, Hyogo 650, Japan
}

(Received 2 October 1992/Accepted 20 January 1993)

\begin{abstract}
It is well known that laboratory rabbits are not controlled genetically like laboratory mice and rats. In order to test the usefulness of DNA fingerprinting in investigation of genetic uniformity of the laboratory rabbits strains and their relationships, we applied DNA fingerprinting using bacteriophage M13 probe to five strains (2 inbreds (JWY-NIBS and DuY-NIBS) and 3 outbreds (JW-NIBS, Icl : JW and WHHL)). DNA fingerprints of 2 inbred strains showed the same banding patterns within each strain but the strainspecific patterns. Although there were no rabbits showing the same banding patterns in 3 outbred strains, average percent differences (APD) were 13.7 to 18.6. A dendrogram based on APD of DNA fingerprints was constructed by 2 large clusters, JW group and $\mathrm{DuY}$. The dendrogram was essentially similar to that based on rabbit mandible measurements. These results suggest that DNA fingerprinting is available not only for the genetic monitoring of the laboratory rabbit strains but also for the investigation of their genetic relationships. - KEY WORDS : DNA fingerprint, genetic monitoring, genetic relationships, Japanese white rabbit
\end{abstract}

\section{実験用ウサギ系統の類縁関係検討への DNA}

$$
\text { フィンガープリント法の適用 }
$$

周藤 俊樹・辻 荘一・万年英之・後藤信男・梅 沢英彦*

水谷 誠*・矢沢肇*・塩見雅志**

神戸大学農学部家畜育種学教室

*財団法人日本生物科学研究所附属実験動物研究所

**神戸大学医学部動物実験施設

我が国で使用されている実験用ウサギとしては，日 本白色種 (日白種, JW), ニュージーランドホワイ 卜種, タッチ種などがあげられる。これらのうち，日
白種が最も多く使用されており，国内約20のブリータ 一によって主としてクローズドコロニーとして維持, 生産され, 系統として供給されている。しかし,この

*** Present address: Toshiki SUDO, Dept. of Pharmacology \& Experimental Therapeutics, Tokushima Res. Inst., Otsuka Pharmaccutical Co. Ltd., 463-10 Kagasuno, Kawauchi-cho, Tokushima 771-01, Japan 
日白種は各種動物実験の諸反応に関して系統間のみな らず個体間でもかなりの差異がみられると言われてい る。

一般に, 系統の遺伝的均一性や系統間の類縁関係を 検討するために多くの方法が適用されているが, 最も 広く用いられている方法はタンパク質多型を支配して いる生化学的遺伝子を利用する方法であろう。野生, 家畜のウサギではこれらに関する多型がかなり多く検 出されているものの, 実験用日白種ウサギ系統ではほ とんど検出されていないために, マウス, ラットにみ られるほどこの方法は有効な手法になっていない。

Jeffreysら [8]によって開発されたDNAフィンガー プリント (DFP) 法は, ゲノムDNA中のミニサテライ トの多型を検出する方法で, ヒトをはじめ各種動物の 個体識別, 親子鑑別に利用されている $[2,8,9,10$, 12]。また, 集団の平均近交係数, 個体間の血縁係数 のDFPのバンディングパターンとの関係など集団の 遺伝的構成や, 集団間の遺伝的類縁関係の推定にも利 用されている $4,5,11,14]$ 。実験動物分野において は, 万年ら [13]は, DFP法が近交系マウスの系統の 同定と類緑関係の推定に有効であることを報告してい る。著者ら[17]は, プローブにM13ファージの反復配 列を用いて，DFP法を実験用ウサギに適用したとこ ろ, 個体識別, 親子鑑別に有効であることを確認し た。そこで，本実験では，このM13ファージ反復配列 をプローブにしたDFP法が, 実験用ウサギ系統の遺 伝的均一性と遺伝的モニタリングおよび系統間の遺伝 的類縁関係をみるのに有効であるかどうかを検討し た。

\section{材料および方法}

供試動物には，日白種ウサギのクローズドコロニー として䝧日生研で維持されているJW-NIBS 10個体, 神戸大学医学部で維持されているWHHL 10個体, (有) 市川屋のIcl：JW 10個体と, 近交系として(財)日生研 で維持されている日白種のJWY-NIBS 4 個体, ダッ チ種のDuY-NIBS 10個体を用いた。クローズドコロ ニー 3 系統の繁殖維持方法については, JW-NIBS は, 雌230個体, 雄28個体からなる6群間のローテーシ ョンシステムで維持されている[18]。WHHLは, 過 去いろいろな繁殖維持方式がとられてきたが $[16$, 19], 現在は1群雌15 20個体, 雄 2 ～個体からなる 6 群で構成され, 各群から冠状動脈狭窄を指標に選抜
された雌, 雄間でローテーションシステムで維持され ている。Icl：JWは, 長野県産の日白種由来で, 雌50 個体, 雄15個体を種動物としてローテーションシステ ムで維持されているものである。JW-NIBS, Icl： $\mathrm{JW}$ は, 兄弟, 従兄弟などの血縁関係にある個体を含 めないように, WHHLは各群からもれなく 1 〜個 体計10個体をサンプリングした。JWY-NIBS, DuYNIBSについては文献 $[7,18,21]$ に詳述されている。

サンプルDNAは，これらの個体から採血した血液 を, フェノール・クロロフォルム抽出法で精製したも のを用いた。この精製DNA10 $\mu \mathrm{g}$ を制限酵素Pst I で 消化後, $1.2 \%, 40 \mathrm{~cm}$ アガロースゲルを用い, $2 \mathrm{~V} /$ $\mathrm{cm}, 90$ 時間の条件で電気泳動を行った。電気泳動 後, DNAを強化ニトロセルロース膜にサザントラン スファーした。プローブにはM13ファージDNA反復

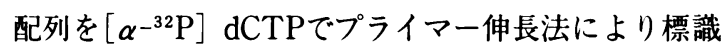
したものを用いた。プレハイブリタイゼーション，八 イブリダイゼーション後の洗浄は, $55^{\circ} \mathrm{C}, 4 \times \mathrm{SSC}$, $0.1 \% \mathrm{SDS}, 30$ 分, 2 回, $55^{\circ} \mathrm{C}, 2 \times \mathrm{SSC}, 0.1 \%$ SDS, 30分, 1 回の条件で行った。洗浄後, オートラ ジオグラフィーにより検出した $[12,17]$ 。

DFPの評価には，次式で表されるaverage percent difference (APD)を用いた[22]。

$$
\mathrm{PD}=\left[\mathrm{F}_{\mathrm{ab}} /\left(\mathrm{F}_{\mathrm{a}}+\mathrm{F}_{\mathrm{b}}\right)\right] \times 100
$$

$\mathrm{F}_{\mathrm{a}}, \mathrm{F}_{\mathrm{b}}$ はそれぞれ個体 $\mathrm{a}, \mathrm{b}$ のバンド数， $\mathrm{F}_{\mathrm{ab}}$ は $\mathrm{a}$ ， b 2 個体間で異なるバンド数を示している。APD は, 集団内あるいは集団間で各個体について pairwise にPDを計算し, 得られた全PDを平均したものであ る。集団内のAPD值は，その集団の遺伝的均一性の 指標となり, 值が低いほど均一性の高い集団であると 推定できる。また, 集団間で算出したAPD値はその 集団間の遺伝的距離となる。系統間のデンドログラム はこのAPD值をもとにUPG (Unweighted PairGroup Clustering)法で作成した。

\section{成}

Fig. 1 は上記 5 系統のDFP像である。1 個体当たり 20〜28本のバンドが検出された。クローズドコロニー の日白種 3 系統は平均 23.5 本で, 同一のバンディンク パターンを示す個体はなかった。近交系のJWY NIBS，DuY-NIBSはともに21本で，それぞれ系統内 で変異がみられず，他の系統と異なるバンディングパ ターンを示し, 近交系として確立されていることが確 

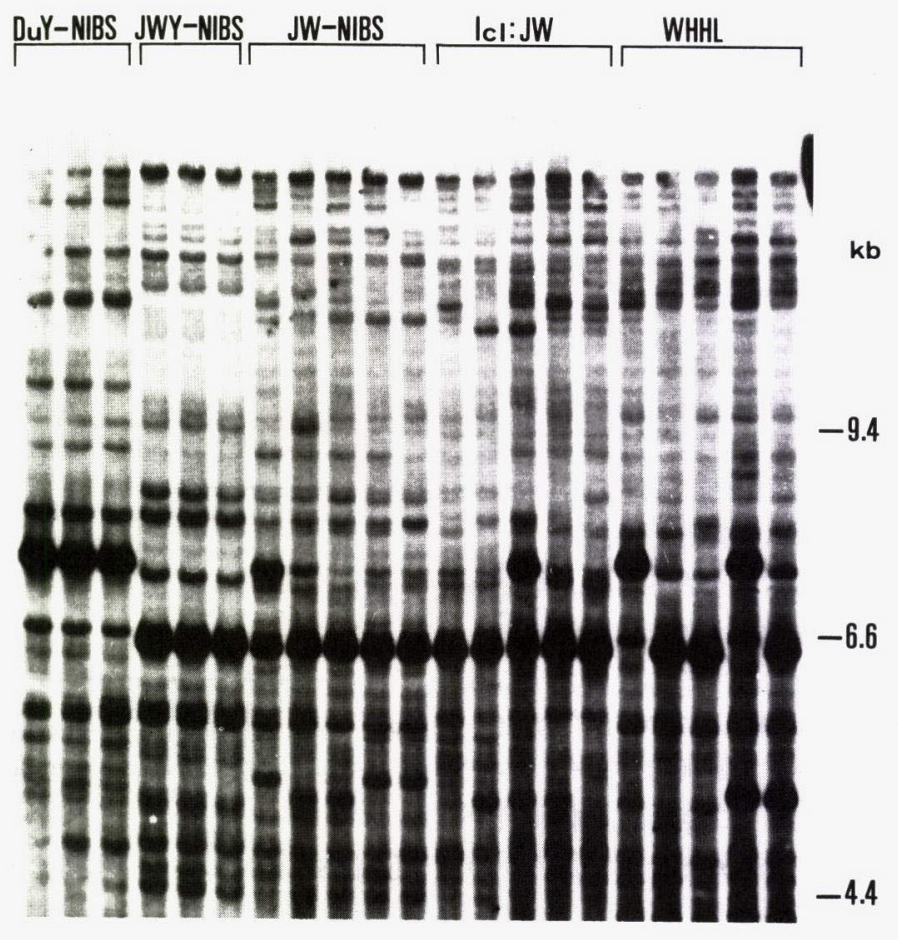

Fig. 1. DNA fingerprints made with a bacteriophage M13 probe on Pst I -digested DNA of 5 strains of laboratory rabbits

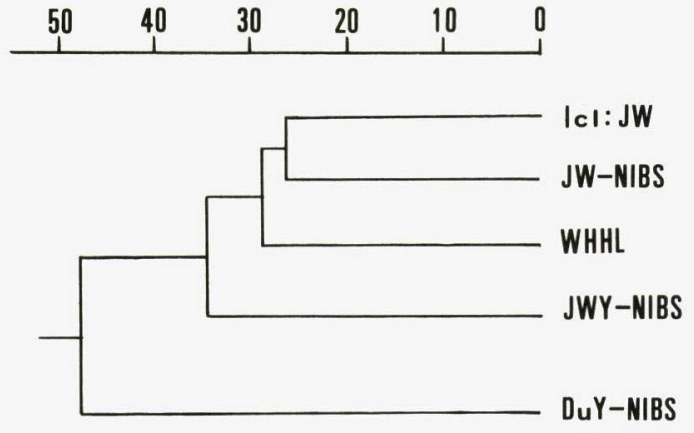

Fig. 2. A dendrogram of 5 strains of laboratory rabbits based on DNA fingerprints. Scale refers to the APD values between strains

認された。また， 5 系統全てに共通なバンドは 5 本， 各系統に特異的なバンドは, JWY-NIBSで 1 本, DuY-NIBSで 4 本, Icl : JWで 1 本, WHHLで 1 本 見られた。このことにより，DFP法は実験用ウサギ 系統の遺伝的モニタリングに有効であることが示され た。Table 1 はこれらのバンドをもとに算出した各系 統内, 系統間のAPD值である。2つの近交系は各系 統内でバンディングパターンに変異がみられないため
にAPD值は 0 になっている。日白種 3 系統のAPD值 はWHHLの13.7からJW-NIBSの18.6とほほ同じ值 を示した。近交系を含めた 5 系統間のAPD值は, (JW-NIBS, Icl : JW)の26.1から (DuY-NIBS, Icl : JW)の 52.2 となったが, クローズドコロニーの日白 種 3 系統間のAPD值は26.1から29.6とよく似た值を 示した。Fig. 2 はTable 1 のAPD值をもとに作成した デンドログラムである。このデンドログラムは, 大き くは日白種とダッチ種の 2 クラスターから形成されて おり, 日白種の中でも近交系のJWY-NIBSとクロー ズドコロニーの 3 系統の 2 クラスターに分類された。

\section{考察}

本実験のDFPにおいて, 近交系のバンド数21本に くらべ,クローズドコロニーの日白種 3 系統は平均 23.5本とやや多かった。この結果は, 近交系のバンド がすべてホモ接合体になっているのに対し, クローズ ドコロニーではホモとへテロなバンドが混在している ためと考えられた。近交系とクローズドコロニーの平 均バンド数の差が 2.5 本と少ないのは, クローズドコ 
Table 1. APD matrix of 5 strains of laboratory rabbits

\begin{tabular}{lccccc}
\hline \multicolumn{1}{c}{ strain } & DuY-NIBS & JWY-NIBS & JW-NIBS & Icl $: \mathrm{JW}$ & WHHL \\
\hline DuY-NIBS & $(0.0 \pm 0.0)$ & $47.6 \pm 0.0$ & $46.5 \pm 7.0$ & $52.2 \pm 4.2$ & $43.9 \pm 4.2$ \\
JWY-NIBS & & $(0.0 \pm 0.0)$ & $33.0 \pm 6.0$ & $40.2 \pm 3.1$ & $30.0 \pm 5.1$ \\
JW-NIBS & & & $(18.6 \pm 6.5)$ & $26.1 \pm 4.3$ & $28.6 \pm 7.0$ \\
Icl $:$ JW & & & & $(17.6 \pm 4.4)$ & $29.6 \pm 5.4$ \\
WHHL & & & & & $(13.7 \pm 5.2)$ \\
\hline
\end{tabular}

Data were expressed as $\mathrm{APD} \pm \mathrm{SD}$.

ロニー 3 系統の維持過程におけるバンドのホモ化によ るものと思われる。

DFP法で検出された各バンドがホモ，あるいはへ テロ接合体であるかを判断する手段として, 同一サイ ズのバンドの濃淡を利用する方法がある $[14]$ 。すなわ ち，ホモなバンドはへテロなバンドのほほ 2 倍の濃さ があるはずなので，この点を比較することによってあ る程度判定できる。しかしながら，この方法はまだ一 般化されておらず, 通常バンドの評価は, ホモ, へテ 口を考虑せずに行われている。このため, 本実験で は，各バンドについてホモであるかへテロであるかの 判定は特に行わなかった。

APD值に関しては, 脊椎動物の野生集団では 70 90, ヒトでは76.9, アフリカライオンの閉鎖集団 では44.5 51.5, カリフォルニア諸島群に生息するキ ツネにおける各島の平均では12.0（0２3.5），などの 報告がある $[4,5]$ 。しかし, APD值は同一の集団でも 使用するミニサテライトプローブの種類によって多少 異なる值を示す $[5]$ 。本研究では, プローブに大腸菌 から哺乳動物まで広くミニサテライトの多型を検出す ることができるM13ファージ反復配列[15]を用いた。 このプローブによる日白種各 3 系統内のAPD值は 13.7 18.6となり, プローブの種類が異なるものの上 記各種野生動物集団の値に比へ低い值を示した。この ことは, これら日白種 3 系統が上記の集団に比べると 遺伝的变異が少ない, すなわち遺伝的均一性が高いこ とを示していると思われるが，今後他のミニサテライ トプローブについても同様な検討を行う必要がある。 クローズドコロニー 3 系統において, WHHLが他の 2 系統にくらべ若干低いAPD值を示したのは, 冠状 動脈の病変面積の選抜 [16]による近交係数の上昇のた めと思われる。また, 日白種 3 系統全体でAPD值は 24.8となったが, この值が品種として高いか低いかを 判断するためには日白種の他系統や他の品種について 調へ，さらに検討する必要があると思われる。

後藤 $[6]$ は15のブリーターで維持されている日本白
( ) : APD value within strain

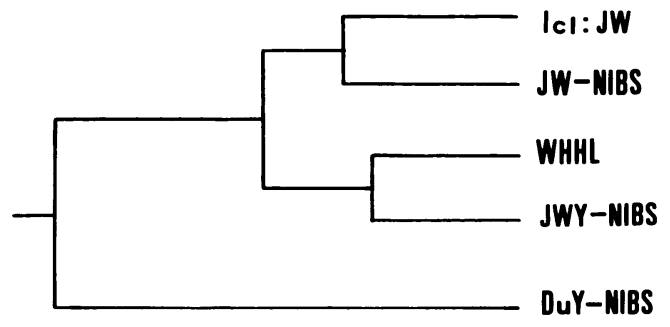

Fig. 3. A dendrogram of 5 strains of laboratory rabbits based on 12 mandible measurements

色種18系統について下額骨分析, 血漿蛋白質多型分析 を行い, これらの系統内の遺伝的均一性, 系統間の遺 伝的類縁関係を検討した。Fig. 3 は, 本報告で用いた 5 系統について，既報 $[6,7]$ の下額骨12部位計測値を 用いてデンドログラムを作成したものである。ただ し,この図は下影骨の大きさを補正したデー夕（各個 体につき全部位計測值の総和を求め, それで各部位計 測值を除した值) をもとにしている。この結果をFig. 2 のDFPにもとづくデンドロクラムと比較すると, 両者とも日白種とタッチ種の 2 クラスターに分類され ており,この点ではほほ一致した結果が得られてい る。Wayne and O'Brien[20]は近交系マウスを用い下 顎骨の形態にもとづく系統間の形態的距離（マハラ） ビスの距離）と生化学的遺伝子座にもとづく遺伝的距 離（Neiの距離）とを比較したところ, 両者間には関 連がないと報告している。しかし, Festing and Roderick [3] は系統として複数の亜系と野生由来の近 交系を加えて, 同様に分析したところ, 両者の間には 高い正の相関がみられたと報告しており，意見の相違 がみられる。本実験において, DFP法による分析結 果 (Fig. 2) では, クローズドコロニー3 系統と近交 系のJWY-NIBSとは別のクラスターを形成している が, 下頧骨分析の結果 (Fig. 3) では, Icl：JWと JW-NIBS, WHHLとJWY-NIBSがそれぞれ別のク ラスターを形成しており，若干の相違がみられた。 JWY-NIBSは, JW-NIBSと同し東京都府中市の農 
家由来の近交系であるが, 基礎個体群の後者系統との 遺伝的構成の相違, あるいは近交系確立過程における 特定の遺伝子型への固定のために，JW-NIBSを含む クローズドコロニーの 3 系統と遺伝的に離れている可 能性がある。

Gilbertら[4]は，カリフォルニア諸島群に生息する キツネの集団間の類縁関係をDFPから算出したAPD 值を用いて推定し，この方法が有効であることを報告 している。DFPは任意の 2 個体間の血縁係数を推定 するのに有効である $[1,5,14]$ 。これはDFPのバンデ イングパターンの類似性, すなわちバンドシェアリン グBS $(=100-\mathrm{PD})$ と血縁関係との間の正の相関を根拠 にしている。しかし，血縁関係のない個体間の平均 BS值が大きい集団では任意の 2 個体間の血縁関係の 推定は困難となる $[1,5]$ 。このように, 個体間あるい は集団間の類縁関係を推定する場合DFP法は若干の 問題点があるものの，本実験の結果によれば下顎骨分 析の結果ともほほ一致しており，DFP法は実験用ウ サギ系統の類縁関係の推定に有効であると思われる。

著者らは, マウス[13], ゴールデンハムスター, マ ストミス[17]の近交系にDFP法を適用し, 本法がこ れらの系統の遺伝的モニタリングに有効であることを 確認している。本実験では，同一近交系内の個体はす ベて同じバンディングパターンを示し，また近交系 間，クローズドコロニー 3 系統内の個体間で同じバン ディングパターンを示す個体はみられなかった。この ことは, DFP法が実験用ウサギ系統の遺伝的モニ夕 リングに有効であることを示唆している。

\section{要 約}

実験用日本白色種（日白種）ウサギは，各種動物実 験における結果の個体差や系統差が指摘されている。 そこで本実験では，M13ファージ反復配列をプローブ にしたDNAフィンガープリント法をダッチ種を含む 実験用ウサギ 5 系統に適用し, 日白種系統の遺伝的均 一性をみるとともに, 本法がこれらの系統の遺伝的モ ニタリングや遺伝的類縁関係の推定に有効であるかど うかを検討した。

近交系 2 系統のDNAフィンガープリントは, 各系 統内で変異がみられず, それぞれ特有のバンディング パターンを示した。またクローズドコロニーの日白種 3 系統では，同一のバンディングパターンを示す個体 はなかったが, average percent difference (APD) 值
は13.7〜18.6となった。実験用ウサギ 5 系統のDNA フィンガープリントのAPDにもとづくデンドログラ ムは, 大きく日白種とダッチ種の 2 つのクラスターか ら形成されていた。この結果は,これら5 系統の下顎 骨12部位計測值にもとづくデンドログラムとほほ一致 していた。これらのことから，DNAフィンガープリ ント法は実験用ウサギ系統の遺伝的モニタリングや類 縁関係の推定に有効であることが示唆された。

\section{文献}

[1] Blanchetot, A. (1992). DNA fingerprinting analysis in the solitary bee Megachile rotundata : variability and nest mate genetic relationships. GENOME, 35, 681688 .

[2]. Burke, T. and Bruford, M. W. (1987). DNA fingerprinting in birds. Nature, 327, 149-152.

[3] Festing, M. F. and Roderick, T. H. (1989) . Correlation between genetic distances based on single loci and skeletal morphology in inbred mice. Genet. Res., 53 , 45-55.

[4] Gilbert, D. A., Lehman, N., O'Brien, S. J., and Wayne, R. K. (1990). Genetic fingerprinting reflects population differentiation in the California Channel Island fox. Nature, 344,764-767.

[5] Gilbert, D. A., Packer, C., Pusey, A. E., Stephens, J. C., and O'Brien, S. J. (1991). Analytical DNA fingerprinting in lions : parentage, genetic diversity, and kinship. J.Hered., 82, 378-386.

[6]後藤信男 (1991). 平成 2 年度科学研究費補助金試験研究 (B) 研究成果報告書

[7] Goto, N., Watanabe, K., Umezawa, H., Yazawa, H., and Kuramasu, S. (1987). Morphometrical observations on the mandible of five strains of rabbits and strain identification using mandible measurements. Lab. Anim ., 21, 188-194

[8] Jeffreys, A. J., Wilson, V., and Thein, S. L. (1985). Hypervariable 'minisatellite' regions in human DNA. Nature, 314,67-73

[9] Jeffreys, A. J., Wilson, V., and Thein, S. L. (1985). Individual-specific 'fingerprints' of human DNA. Nature, 316, 76-79.

[10] Jeffreys, A. J., Wilson, V., Thein, S. L., Weatherall, D. J., and Ponder, B. A. J. (1986) . DNA 'fingerprints' and segregation analysis of multiple markers in human pedigrees. Am.J.Genet., 39, 11-24

[11] Kuhnlein, U., Zadworny, D., Dawe, Y., Fairfull, R. W., and Gavora, J. S. (1990). Assessment of inbreeding by DNA fingerprinting : development of a calibration curve using defined strains of chickens. Genetics, 125, 161-165.

［12］万年英之・过 荘一・向井文雄・後藤信男 (1992)．M137 アージ反復配列をプローブとしたウシのDNAフィンガー プリント分析. 日畜会報, 63, 928-934.

[13] Mannen, H., Tsuji, S., Goto, N., and Fukuta, K. (1993). Identification of inbred strains of mice and genetic relationships between strains as assessed by DNA fingerprinting. Exp.Anim., 42, 169-173.

[14] Mannen, H., Tsuji, S., Mukai, F., Goto, N., and Ohtagaki, S. (1993). Genetic similarity using DNA 
fingerprinting in cattle to determine relationship coefficient. J. Hered., (in press)

[15] Ryskov, A. P., Jincharadze, A. G., Prosnyal, M. I., Ivanov, P. L., and Limborslaya, S. A. (1988). M13 phage DNA as a universal marker for DNA fingerprinting of animals, plants and microorganism. FEBS, 233, 388-392.

[16] Shiomi, M., Ito, T., Shiraishi, M., and Watanabe, $Y$. (1992). Inheritability of atherosclerosis and the role of lipoproteins as risk factors in the development of atherosclerosis in WHHL rabbits : Risk factors related to coronary atherosclerosis are different from those related to aortic atherosclerosis. Atherosclerosis, 96, 43-52.

［17］周藤俊樹・万年英之 ·过 荘一・後藤信男 (1992). DNA ᄀ インガープリント法の実験動物への応用. 動物血液型蛋白
質多型研究情報, 20, 27-31

［18］上田 進［編集］（1982）。小淵沢15年のあゆみ. pp23-44， (財)日本生物科学研究所, 東京.

[19] Watanabe, Y. (1980). Serial inbreeding of rabbits with hereditary hyperlipidemia (WHHL-rabbit). Atheros. clerosis, 36, 261-268.

[20] Wayne, R. K. and O'Brien, S. J. (1986) . Empirical demonstration that structual gene and morphometric variation of mandible traits are uncoupled between mouse strains. J. Mamm., 67, 441-449.

（21］矢沢 梅沢英彦・倉益茂実・宮嶋正康 (1986)。ウサキ の近交系の確立. 実験動物, 35，203-206.

[22] Yuhki, N. and O'Brien, S. J. (1990). DNA variation of the mammalian major histocompatibility complex reflects genomic diversity and population history. Proc. Natl. Acad. Sci. USA, 87,836-840. 